\title{
Philatelic Diplomacy in the System of the Global Economic Cooperation and Its Role in Realization of the Geopolitical Goals
}

\author{
Andrey Vadimovich Strygin \\ Moscow Automobile and Road State Technical University (MADI); Email: strygin@inbox.ru
}

Doi:10.5901/mjss.2015.v6n5s3p356

\begin{abstract}
This article describes a concept of philatelic diplomacy as one of the categories of geopolitics. It considers the origin and genesis of philatelic diplomacy as a form of «people's diplomacy», as well as its correlation with the stamp market as one of the directions for the development of the global economic cooperation. With particular focus on enhancement of the role of philatelic diplomacy at the present stage of the geopolitical infighting. The issues covered in the present article appear not only relevant and valid from politico-social point of view, but are also undoubtedly innovative in two aspects: the global character of presentation of a problem and the specificity of the attained results.
\end{abstract}

Keywords: geopolitics, geo-finances, global economic cooperation, stamp market, philatelic geography.

\section{Introduction}

The First International Conference devoted to development challenges of so-called "non-traditional business" was held in late 1991 in the Moscow Academy of Management. This definition combined such areas of business activities as business in education, business in entertainment, business in hobbies and interest spheres, which were really nontraditional during that period of time (Strygin A.V., 1991, 64 p.). This launched the studying of this area of business activities in its complex relationship with social and political development of the society, which was before left out of consideration in the USSR.

Generally, social, acting outside professional, activity of the people, makes itself evident in two directions: public activity and so-called hobbies, in other words, interests, giving a chance of self-actualization, or in the form of one or another amateur creative work. As it is widely recognized, the most popular and available direction in this sphere is collecting, which originated deep in ancient times and has now several dozens of popular forms of collecting worldwide, the most widespread and available of which, according to the data of the United Nations Organization, is philately collecting of indicia.

\section{Materials and Methods}

In the function of the main materials the publication (Brodel F., 1949-1966 \& Brzezinski Z., 1994) are used and their comparative study constituted the subject matter of the present article.

Total infatuation with philately was followed by development of the commercial infrastructure, which provides services to collectors. Trading network with lots of selling spots appeared, where complimentary to primary services at post offices you could purchase some stamps required and other goods related or following-up your collections; then auction houses and stamp exhibition and trade fair activities developed.

In addition, increase in sales and turnover by issuers of the postage stamps, which, in accordance with the standards of the Universal Postal Union (UPU) and The World Association for the Development of Philately (WADP), may be only the government postal authorities, the higher commercial sales of collectors' items and materials (secondary trading, through a dealer network and auction bidding), and also increase in philatelist-oriented editorial production - all of them resulted in creating of the international structure, which consists of professionally connected, by their aims and objectives, world associations, such as, for example: ASCAT (Association internationale des éditeurs de catalogues de timbres-poste, d'albums et de publications philatéliques), IFSDA (International Federation of Stamp Dealer Associations). There are also some international unions of collectors which are in close cooperation with the above-mentioned organizations, in particular: FIP (Fédération internationale de philatélie) and its regional analogues in Europe (FEPA), Asia (FIAP) and America, AIJP (Association Internationale des Journalistes Philateliques) and Association Internationale 
des Experts Philateliques, members of which provide expert opinions on the authenticity of rare and valuable collectors material.

Eventually, since the end of the Second World War the meaningful structure of the international stamp market has been formed, however, for several reasons the collectors from the USSR were artificially isolated from it. When in the early 1990s they started to engage to and act actively in the stamp market, the above-mentioned definition of "nontraditional business" appeared. And the first attempt of its methodological learning and understanding was the International Conference "Business and Philately in the Modern World" which was held in Moscow.

\section{Results}

The attained results are based on the consideration of a wide range of views on the research which was carried out.

In the Soviet Union philately was considered as a form of ideological propaganda. While looking back, we can say that, when in 1923 Vladimir.Lenin ordered to establish the foreign trade association "Mezhdunarodnaya Kniga", its responsibilities included those of selling or otherwise trading of the Soviet philatelic material in the foreign market. At the same time, the structure of the state philately was founded in the USSR with its supervisor - the People's Commissar F.Chuchin, who suggested (on the initiative of F.Nansen, concerned about a severe famine in Povolzhye and some other regions of the Soviet Russia) not only to arrange all necessary things for stamps collecting and their onward sale abroad in order to forward the money received to the fund to help the starving ones, but also to organize a so-called "foreign stamp exchange" for the Soviet collectors and their partners abroad. There was the ideological foundation of this proposal - a total, yet absolutely legal, control over the entire private correspondence to and from abroad, containing philately items (The world of stamps and coins, 2014, 96 p). Incidentally, sometime later the similar practice, although more veiled, was organized in the post war GDR, where some important correspondence on the ground of its preservation was forced to be sent by the system of the central courier service. It had special spots for "repackaging" and additional franking with special courier stamps, where the package content could be also checked, without being detected Kobersy I., Karyagina A., Karyagina O., \& Shkurkin D. (2015).

Along with this, propagandistic and ideological functions of philately in the USSR and the other countries which were its political allies were actualized in the subject of the postal emission activities, when Soviet postal stamps depicted political slogans, resolutions of the Communist Party Congresses and Conferences, in order to irrigate public opinion with the communist principles. For the justice's sake, it should be noted that in the Western countries stamps were also used as a good means of political propaganda, showing the level of the Western research and technology, as well as the Western democracy, and their emission activities during the second part of the $20^{\text {th }}$ century serves as evidence of that.

\section{Discussion}

Politico-social aspect of the debated subject is reflected in comparison of the positions of different researches of this global problem.

It is to be noted that although the conceptual and logical structure has been formed recently according and is relatively young by time standards, it is in demand in the modern world of science, especially in geo-economics (Kochetov E.G., 2010, 528 p), including not only geographical imperative, which expresses the connection between the economy and the area of its functioning, and specifically the regional localization, but also the synthesis of the economic and political spheres in the fields of international, and mostly, monetary and financial (geo-finances) relations, which is fully compatible with its traditional subject matter, as well as the politics and strategy of public sector competitiveness in the context of globalization of the world economy. In other words, the realization of the geopolitical goals is achieved through a mechanism of geo-economics based on the conscious selection of geo-strategy. This idea was once already regarded by F.Brodel, who gave a detailed description of its realization in his remarkable study of the Mediterranean Sea and Mediterranean World in a distant time (Brodel F., 2003, 426 p). He indicated the influence of the spatiography over the geography of the economy management, economic geography in the "Annales" magazine which he edited. This magazine had rather clear subheadings "Economies, sociétés, civilisations", placing the author into historians and naming him the founder of the geo-history. And consequently, in the world science F.Brodel was placed both in history and sociology fields (as we know, sociology was emerged at the crossroads of history and philosophy). But in the same way we can place F.Brodel (Brodel F., 1945) and Edward Luttwak (Luttwak E., 2012, 392 p) into sociologists or demographists, since they both conducted rather in-deep researches on human relations and human behaviours in different economic systems, ranging them on the grounds of demographic factors, including behavioural characteristics, which can be realized by "positive dependency" through the mechanism of hobbies. The most popular among those is 
collecting, and first of all - philately Kobersy, I., Karyagina A., Karyagina O., \& Shkurkin D. (2015).

A concrete demonstration of philatelic geopolitics in the context of mediated perception of the world are the following facts.

Firstly, each new independent state (their number after the Second World War and national-liberation movement that followed was getting increased), together with declaration of the flag, state emblem and hymn inalterably sets up the emission of its own postage stamps, ranking them in one row with traditional attributes of national identity. Furthermore, independently of each other in the post war Europe two leaders of the countries which were on opposite sides of the geopolitical confrontation: G.Dimitrov in Bulgaria and Ranier III, Prince of Monaco, they gave identic definitions for postage stamps as "brand identity of the country" (Strygin A.V., 1990., 37 p), therefore, postage stamps were practically declared as the fourth symbol of the nationhood.

Secondly, different countries announce their involvement in various global geopolitical communities through postage stamps. They do it either declaring openly their union with another country by placing on the stamps next to their flags and state emblems the same attributes of the nationhood of a superpower of the second part of the last century; or using the practice of a joint stamp issuing, when two or more countries, emphasizing their political union, simultaneously issue postage stamps with the same subject Kobersy I., Karyagina A., Karyagina O., \& Shkurkin D. (2015).

Here we must emphasis the importance of the international movement "Rossika" and its efforts for the promotion of the Russian regional philately worldwide, and also the popularization abroad of indicia collecting of the periods: the Russian Empire - the USSR - the Russian Federation. The importance of their activities is amply demonstrated by the official congratulations of S.Lavrov, the Minister of Foreign Affairs of the Russian Federation. It was received by the organizers of the International Philatelic Exhibition "Rossika-2014". In his address the Minister highlighted the role and importance of philately as one of the directions of people's diplomacy, which is emerging nowadays, its role in the process of "getting the general public better informed on an important part of cultural and historical heritage of our country, in the development of international humanitarian cooperation" (The world of stamps and coins, 2015, 80 p).

\section{Conclusion}

And the more often such conferences take place the more appreciable is the cumulative impact on the subconscious level of the general public, who are using stamps for practical purposes alone, i.e., for franking postal consignments, and during this process associations and connections between the subjects of the stamps and the real country of Russia the improvement of its image creates.

By that, philately, officially and at the diplomatic level, is conducting the cultural and educational functions and activating and forming abroad the Russian-oriented geo-cultural and geo-philatelic areas. Philatelic diplomacy reflects the processes of globalization, and characterizes the change of attitudes in the modern picture of the world of individuals, their search for the ideal in modern society (Karabulatova, 2013, 793 p.; Khachmafova, Karabulatova, Luchinskaya \& Osipov, 2015 \& Ostrovskaya, Karabulatova, Khachmafova, Lyaucheva \& Osipov 2015). The visual image of the brand is strengthening effect clip-thinking (Karabulatova, 2013, 794 p).

Development of the international communications in XXI century clearly demonstrates not only the increasing role of geopolitics in the circumstances of political and economic cooperation and competition of three centers of the world economy, which determine the main trends in activating of the international economic relations, but also cumulative indirect impact of humanitarian factors on shaping and correcting people's aware attitudes in different countries to the policy taken by their state authorities, which in some cases can even encourage them to change it.

\section{References}

Brodel, F. (1966) La Mediterranee et le Monde Mediterraneen a l'epoque de Philipe II.La Part 1-3. Paris.

Brodel, F. (1945) Civilisation Matérielle, Economie et Capitalisme XVe-XVIIIe Siècle. trans. from French. 3 vol. M: Progress.

Brodel, F. (2003) The Mediterranean and the Mediterranean World in the Age of Philip II. trans. from French.- M: LRC Publishing House. pp. 426.

Brzezinski, Z.K. (1997) The grand Chessbook. NY.: Basic books.

Kobersy, I., Barmuta K., Muradova S., Dubrova L., \& Shkurkin D. (2015). The System of the Methodological Principles of Management of Enterprise Development. Mediterranean Journal Of Social Sciences, 6(3 S4), 25. Retrieved from http://www.mcser.org/journal/ index.php/mjss/article/view/6707

Ebeling, F. (1994) Karl Haushofer und seine Raumwissenschaft 1919-1945.-Berlin. Akademien Verlag.

Karabulatova, I.S. (2013) The problems of linguistic modeling of new Eurasian linguistic personality in multilinguistic and mental environment (by example of onomasphere) // Middle-East Journal of Scientific Research 17 (6): 791-795. ISSN 1990-9233.C 
IDOSIPublications, 2013.DOI: 10.5829/idosi.mejsr.2013.17.06.12262. http://www.idosi.org/mejsr/mejsr17(6)13/15.pdf http://www. idosi.org/mejsr/mejsr17\%286\%2913.htm.

Kochetov, E.G. (2010) Geo-economics. Development of the World Economic Space: textbook for the higher education sector. M: Norma. pp. 528.

Khachmafova, Z.R., Karabulatova I.S., Luchinskaya E.N. \& Osipov G.V. (2015) Gender Features of Discourse of Woman's Literature as a Reflection of Changes in the Modern Society. In the: Mediterranean Journal of Social Science. 2015. Vol 6, No3, S.2. pp. 476481. Doi:10.5901/mjss.2015.v6n3s2p476. http://www.mcser.org/journal/index.php/mjss/article/view/6528/6255

Luttwak, E. (2012) Strategy: The Logic of War and Peace. trans. from English. M: PH of the Russian Support Fund for Education of the University named after Dmitry Pozharsky. pp. 392.

Ostrovskaya, T.A., Karabulatova I.S., Khachmafova Z.R., Lyaucheva S.A. \& Osipov G.V. (2015) The Discourse of the Russian Elite in the ERA "Liquid" Modernity as a Problem of Ethnic, Social and Cultural Security. In the: Mediterranean Journal of Social Science. Vol 6, No3, S4. pp. 147-154. http://www.mcser.org/journal/index.php/mjss/article/view/6723/6437.

The world of stamps and coins (2014) Almanac / edited by A.V. Strygin. Special issue. - M: PH "Biblio-Globus". pp. 96.

The world of stamps and coins (2015) Almanac 11 / edited by A.V. Strygin. M, PH "Uley". pp. 80.

Strygin, A.V. (1991) Non-traditional business. M: Znanie. pp. 64.

Strygin, A.V. (1990) Hobby of the Century. M: Molodaya Gvardia. pp. 37.

Kobersy, I., Karyagina A., Karyagina O., \& Shkurkin D. (2015). Law as a Social Regulator of Advertisement and Advertising Activity in the Modern Russian Information Space. Mediterranean Journal Of Social Sciences, 6(3 S4), 9. Retrieved from http://www.mcser. org/journal/index.php/mjss/article/view/6705 